\title{
Seasonal Variations in Fatty Acid and Nutritional Composition of Sand Smelt (Atherina boyeri) caught from Cekerek Dam (Yozgat, Turkey)
}

\section{Esra BALIKÇI ID}

Department of Gastronomy and Culinary Arts, Faculty of Tourism, Yozgat Bozok University, Yozgat, Turkey

*Corresponding Author: esra.balikci@bozok.edu.tr

Received 26 January 2021; Accepted 25 April 2021; Release date 01 September 2021.

How to Cite: Balıkçı, E. (2021). Seasonal variations in fatty acid and nutritional composition of Sand Smelt (Atherina boyeri) caught from Cekerek Dam (Yozgat, Turkey). Acta Aquatica Turcica, 17(3), 409-420. https://doi.org/10.22392/actaquatr.868642

\begin{abstract}
Seasonal variations of proximate and fatty acid compositions of the muscle tissue of sand smelt (Atherina boyeri) harvested in Cekerek (Sureyyabey) Dam were investigated. Seasonal nutritional composition of sand smelt muscle in October, March and July were found as $17.00 \% ; 16.72 \% ; 15.64 \%$ for protein, $1.95 \% ; 2.00 \%$; $2.86 \%$ for lipid, $79.25 \%$; $79.17 \% ; 78.06 \%$ for moisture and $1.80 \% ; 2.10 \% ; 2.49 \%$ ash, respectively. Sand smelt showed the lowest protein values in summer, while the highest protein values were observed in autumn and spring. The highest lipid content of sand smelt was found in summer $(\mathrm{P}<0.05)$. The moisture content of sand smelt in summer was significantly $(p<0.05)$ lower than those of the content in autumn and spring. The lowest ash content was observed in autumn $(1.80 \%)$ whereas sand smelt gave the highest ash level was in summer. During the seasons, the proximate and FA composition values of sand smelt showed variations $(\mathrm{p}<0.05)$. Seasonal fatty acid compositions of sand smelt ranged from 24.63 to $25.69 \%$ for saturated fatty acid (SFA), from 20.75 to $26.43 \%$ for monounsaturated (MUFA), and from $28.29 \%$ to $36.11 \%$ polyunsaturated fatty acid (PUFA). Palmitic

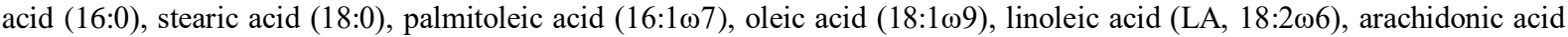

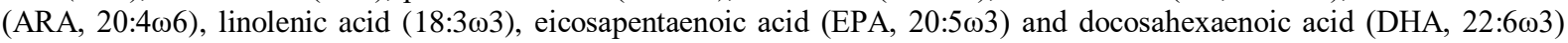
were major fatty acids of sand smelt in different seasons. The highest proportion of EPA (5.59-7.22\%) and DHA (12.33$19.77 \%$ ) were observed in spring. The results showed that sand smelt is good source of $n-3$ PUFAs and is rich in EPA+DHA for human nutrition.
\end{abstract}

Keywords: Cekerek (Sureyyabey) Dam, DHA/EPA, nutritional composition, Sand smelt, seasonal variation in fatty acids.

Çekerek Barajı'ndan (Yozgat, Turkey) Avlanan Gümüş Balığının (Atherina boyeri) Yă̆ Asidi ve Besin Kompozisyonundaki Mevsimsel Değişimleri

Özet

Çekerek (Süreyyabey) Barajı'nda avlanan gümüş balığının (Atherina boyeri) besinsel ve yağ asidi kompozisyonunun mevsimsel değişimleri araştırılmıştır. Gümüş balığının mevsimsel besin kompozisyonu Ekim, Mart ve Temmuz aylarında sirasıyla protein için $\% 17,00 ; \% 16,72 ; \% 15,64$, lipid için $\% 1,95 ; \% 2,00 ; \% 2,86$, nem için $\% 79,25 ; \% 79,17 ; \% 78,06$ ve kül için \%1,80; \%2,10; \%2,49 olarak bulunmuştur. Gümüş balığında en yüksek protein değerleri sonbahar ve ilkbaharda gözlenirken, en düşük protein değeri yazın gözlenmiştir. Gümüş balığının en yüksek yağ oranı yaz mevsiminde gözlenmiştir $(\mathrm{p}<0,05)$. Gümüş balığının yaz mevsimindeki nem içeriği sonbahar ve ilkbahar mevsimindeki nem içeriğinden önemli ( $<<0,05)$ ölçüde düșüktü. En düşük kül oranı sonbaharda görülürken, gümüș balığının en yüksek kül oranı yaz mevsiminde görülmüştür. Gümüş balığının besin ve yağ asidi kompozisyonu mevsimler boyunca değişkenlik göstermiştir $(\mathrm{p}<0,05)$. Gümüş balığının mevsimsel yağ asidi bileşimleri doymuş yağ asidi (SFA) için \%24,63 ile \%25,69, tekli doymamış yağ asidi (MUFA) için \%20,75 ile \%26,43 ve çoklu doymamış yă asitleri için (PUFA) \%28,29 ile \%36,11 arasında değişim

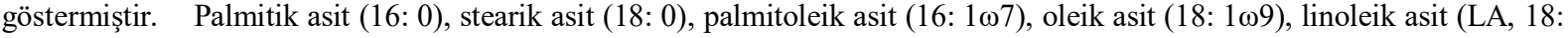

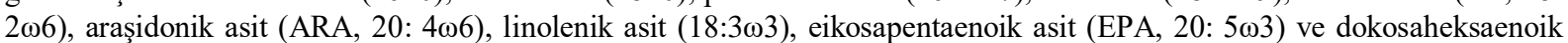
asit (DHA, 22: 6ஸ3) gümüş balığının farklı mevsimlerdeki başlıca yağ asitleriydi. En yüksek EPA $(\% 5,59-7,22)$ ve DHA (\%12,33-19,77) oranı ilkbaharda görülmüştür. Sonuçlar, gümüş balığının iyi bir n-3 PUFA kaynağı ve insan beslenmesi için EPA + DHA açısından zengin olduğunu göstermiştir.

Anahtar Kelimeler: Çekerek (Süreyyabey) Barajı, DHA / EPA, besin kompozisyonu, Gümüş balı̆̆ı, yağ asitlerinde mevsimsel değişimler. 


\section{INTRODUCTION}

Fish and fish products are completely nutritious owing to their low fat, rich in high-quality proteins and contain high component of precious $₫ 3$ polyunsaturated fatty acids (PUFAs), long muscle fibers, liposoluble vitamins, essential minerals, and all essential amino acids that make up beneficial food sources (Ali et al., 2019; Fallah et al., 2013; Lauriano et al., 2018; Mahadevan et al., 2019). Recently, there has been an increasing interest in the fatty acid composition of fish and fish products due to their nutritional and numerous health benefits.

The $₫ 3$ PUFAs contain $\alpha$-linolenic acid (ALA), docosahexaenoic acid (DHA), eicosapentaenoic acid (EPA) whereas the main $₫ 6$ PUFAs include linoleic acid (LA) and arachidonic acid (ARA), which have an important role in human health (Abedi and Sahari 2014; Robert et al. 2014). $₫ 3$ fatty acids are valuable especially EPA and DHA for humans, preventing coronary artery disease, inflammatory and autoimmune disorders, and arrhythmias (Connor 2000; Kinsella 1987; Alexander Leaf et al. 2003; Özogul et al. 2009; Schmidt et al. 2005; Simopoulos 1991) as well as other diseases such as hypertension, atherosclerosis, arthritis, asthma, psoriasis, and cancer (Fallah et al. 2013; Gogus and Smith 2010). In addition, $₫ 3$ PUFAs seem to play the main role in the improvement and function of the nervous system (brain), photoreception (vision), and reproductive system (Alasalvar et al. 2002; Prato and Biandolino 2012; Sidhu 2003).

The $₫ 3$ and $₫ 6$ polyunsaturated fatty acids are considered essential since they cannot be synthesized in the human body, thus they must be provided by food. Hence, every kind of fish should be consumed two or three times a week, advised by the Nutrition Committee of the American Heart Association (Kris-Etherton et al. 2002; Özogul et al. 2009). However, previous studies imply that nutrient contents of most fish species are more irregular in their fatty acid (FA) profiles due to environmental factors, such as feeds, temperature, salinity, and FA composition of their nutrition (Bandarra et al. 2001; Inhamuns and Franco, 2008; James Henderson and Tocher, 1987; Massresha et al. 2017; Ozogul et al. 2011).

Atherina boyeri (sand smelt) is a small, short-lived, euryhaline fish generally living in freshwater hypersaline and forming large local populations. It is spread from the south of Spain to Morocco and Madeira in the Mediterranean, Black Sea, and Atlantic, and in isolated populations on the coasts of England and the Netherlands (Chrisafi et al., 2007; Quignard \& Pras, 1986). It is also found the Caspian Sea (Ekmekçi et al., 2013). The species is very well adapted to the ecosystem it enters, grows quickly, and produces large populations due to the wide range of food and habitat preferences (Ekmekçi et al., 2013). Recently, sand smelt has entered into many natural and artificial lakes in different parts of Turkey (Becer and Bilgin, 2018). The first records of A. boyeri in Cekerek (Süreyyabey) Dam, one of the largest dams in Turkey was given by Benzer (2018).

Sand smelt (Atherina boyeri) has become an important and economic species that both exports and contributes to the region's and Turkey's economy (Becer and Bilgin, 2018; Çevik et al., 2018). Sand smelt can be processed in different methods including drying (Abou-Zied et al., 2020), fish finger (Izci et al., 2011a), fish chips (Izci et al., 2011b), fried big-scale sand smelt (Atherina boyeri) (Dal Bosco et al., 2019). In Turkey, its catch has been reported as 4744 tons in 2019 according to the Turkish Statistical Institute. For this reason, sand smelt (Atherina boyeri) is among the commercially important fish species found in Cekerek (Sureyyabey) Dam (in Yozgat, Turkey). To our knowledge, no previous study exists on the effects of seasonal variations on the proximate and fatty acid composition of this important species in Cekerek (Sureyyabey) Dam. Therefore, the objective of this study was to determine the seasonal variations in proximate and fatty acid profiles muscle tissue of sand smelt (Atherina boyeri) caught in the Cekerek (Sureyyabey) Dam.

\section{MATERIAL and METHODS \\ Fish samples}

Sand smelt (Atherina boyeri) used in the present study were obtained from the local fisherman of Cekerek (Sureyyabey) Dam just after catching, between October 2018 and July 2019. A minimum of thirty fish from each species was collected in October, January, March, and July for each season except during the reproduction season which is in the period between April and June. After catching, fish species were immediately iced in a styrofoam box with ice and transported to the Seafood Processing Technology Laboratory of the Fisheries Faculty at Cukurova University. The duration of time between harvesting and arrival of the fish at the laboratory was 5-6 hours, where they were 
always kept on ice during transportation. After that, whole fish were labeled and frozen at $-24^{\circ} \mathrm{C}$ and kept under frozen conditions $\left(-24{ }^{\circ} \mathrm{C}\right)$ until analyzed. Proximate and fatty acid composition analyses were done within 2 months after sampling. At the beginning of each analysis, the frozen fish was thawed in a refrigerator $\left(2-4^{\circ} \mathrm{C}\right)$ overnight. After thawing, the length and weight measurements of the fish were taken. The mean length and weight values were $7.71 \pm 0.76 \mathrm{~cm}$ and $4.24 \pm 1.31 \mathrm{~g}$ in October; $8.49 \pm 0.57 \mathrm{~cm}$ and $6.34 \pm 1.52 \mathrm{~g}$ in March; $6.98 \pm 0.45 \mathrm{~cm}$ and $3.11 \pm 0.56 \mathrm{~g}$ in July for sand smelt. Then, the fish was immediately gutted, filleted, and minced for chemical composition analyses. Triplicate analyses were made.

\section{Proximate analysis}

The contents of ash and moisture were determined according to the method in AOAC (1984). Protein content was carried out by Kjeldahl's method (AOAC 981.10, 1998). Lipid content was determined by the method of Bligh and Dyer (1959).

\section{FAME analyses}

Methyl esters were prepared by transmethylation using $2 \mathrm{M} \mathrm{KOH}$ in methanol and n-heptane according to the method as described by Ichihara et al. (1996) with minor modification. Extracted lipids $(10 \mathrm{mg}$ ) were dissolved in $2 \mathrm{ml}$ heptanes followed by $4 \mathrm{ml}$ of $2 \mathrm{M}$ methanolic $\mathrm{KOH}$. The tube was then vortexed for $2 \mathrm{~min}$ at room temperature. After centrifugation at $4000 \mathrm{rpm}$ for $10 \mathrm{~min}$, the heptanes layer was taken for GC analyses.

\section{Gas chromatographic condition}

The fatty acid composition was analyzed by GC Clarus 500 with an autosampler (Perkin Elmer, USA) equipped with a flame ionization detector and a fused silica capillary SGE column (30 $\mathrm{m} \times 0.32$ $\mathrm{mm}$, ID x $0.25 \mathrm{~lm}, \mathrm{BP} 200.25 \mathrm{UM}$, USA). The oven temperature was $140{ }^{\circ} \mathrm{C}$, held $5 \mathrm{~min}$, raised to 200 ${ }^{\circ} \mathrm{C}$ at a rate of $4{ }^{\circ} \mathrm{C} / \mathrm{min}$ and to $220^{\circ} \mathrm{C}$ at a rate of $1{ }^{\circ} \mathrm{C} / \mathrm{min}$, while the injector and the detector temperature were set at $220^{\circ} \mathrm{C}$ and $280^{\circ} \mathrm{C}$, respectively. The sample size was $1 \mu \mathrm{L}$ and the carrier gas was controlled at $16 \mathrm{psi}$. The split used was1:100. Fatty acids were identified by comparing the retention times of FAME with a standard 37 component FAME mixture (Supelco). Three replicates of $\mathrm{GC}$ analyses were carried out and the results were expressed in GC area $\%$ as mean value \pm standard deviation (SD).

\section{Statistical Analysis}

Analysis per sample was carried out in triplicate and the results are shown as the average and standard deviation. All data obtained separately for each sampling period were subjected to analysis of variance (one-way ANOVA) and the Duncan's Multiple Range Test was applied to determine significant differences at a $\mathrm{p}$-value of $<0.05$ using the SPSS version 22 software (SPSS, Chicago, Illinois).

\section{RESULT and DISCUSSION Proximate composition}

The seasonal variations in proximate composition values of muscle tissues of sand smelt are presented in Table 1. Protein contents of sand smelt samples in all seasons ranged from $15.64 \%$ to $17.00 \%$ and statistical differences were found in summer $(\mathrm{p}<0.05)$. Sand smelt showed the lowest protein in summer, while the highest protein values were observed in autumn and spring. The average length and weight of sand smelt were also higher in spring and autumn than in summer (Table 1). Izci et al. (2011) and Smida et al. (2014) reported similar protein contents for sand smelt, while Dal Bosco et al. (2019) reported slightly higher protein content (18.40\%) for sand smelt from Tunisian Coast. The differences in protein contents may be attributed to fish size, genetic factors, gender, and seasonal variations. Many previous studies (Köse et al. 2010; Effiong and Mohammed, 2008)) have also shown that the protein composition of fish can change depending on the fish species, size, gender, and season.

The highest lipid content of sand smelt was observed in summer as $2.86 \%$, with significant variation amongst seasons $(\mathrm{p}<0.05)$ (Table 1). The lipid contents of sand smelt in the current study were similar to the results of previous studies (Dal Bosco et al. 2019; Prato and Biandolino 2012). Moreover, Bouriga et al. (2014) also found that the fat content of the sand smelt (Atherina lagunae) populations from Kerkennah Islands and Bizerta Lagoon were maximal at the end of spring beginning of summer and minimal at the end of the winter. The increase of lipid content in summer may also be explained by an increased feeding activity and growth rate of fish because of higher water temperature (Bouriga et al., 2014). However, Yavuzer (2020) reported a higher lipid level (3.58\%) for 
sand smelt from Hirfanlı Dam, Turkey in November. This author also found that the size of the sand smelt was higher (between 11-18 cm) compared to the current study and its weight was similar and lower (between 1-3 g) than our research data (Table 1). The differences in fat contents may be based on regional fish diet, gender, size, and age. Moreover, it was found that the lipid content of fish is influenced by gender, species, season, diet and geographical origin (Ackman, 1989; Özogul et al., 2007; Rasoarahona et al., 2005).

The moisture content varied from $78.06 \%$ to $79.25 \%$ for sand smelt and in summer was significantly $(\mathrm{p}<0.05)$ lower than those of the content in autumn and spring (Table 1$)$. The lowest ash content was observed in autumn whereas sand smelt gave the highest ash level was in summer ( Table 1). Ash contents of sand smelt samples in all seasons were statistically different $(p<0.05)$. Izci et al. (2011a) and Bilgin et al. (2011) also found similar moisture and ash contents of sand smelt. However, Yavuzer, (2020) reported lower moisture content (76.27\%) and higher ash content (3.33\%) for sand smelt compared to the current study.

The proximate and fatty acid composition of fish muscle tissue varies from species to species and is also affected by several factors for singular or many fish of the same species taken at different times or under different situations (James Henderson and Tocher 1987; Tanakol et al. 1999; Vasconi et al. 2015). These factors contain the fish species, size, age, and reproductive cycle of the fish, season, salinity, type of breeding and nutrition, spawning time, geographic location, and water temperature (Linhartová et al. 2018). In summary, it can be said that sand smelt is a good protein source and its nutritional composition varies according to the seasons and these specific factors.

Table 1. Proximate composition (\%), average total length and weight of sand smelt in Cekerek (Süreyyabey) Dam Lake in different seasons.

\begin{tabular}{|c|c|c|c|c|}
\hline $\begin{array}{l}\text { Common and } \\
\text { The species name of fish }\end{array}$ & Composite & $\begin{array}{l}\text { Autumn } \\
\text { (October) }\end{array}$ & $\begin{array}{l}\text { Spring } \\
\text { (March) }\end{array}$ & $\begin{array}{l}\text { Summer } \\
\text { (July) }\end{array}$ \\
\hline Sand smelt. & Protein & $17.00 \pm 0.14^{\mathrm{a}}$ & $16.72 \pm 0.43^{\mathrm{a}}$ & $15.64 \pm 0.15^{\mathrm{b}}$ \\
\hline \multirow{5}{*}{ (Atherina boyeri) } & Lipid & $1.95 \pm 0.50^{\mathrm{b}}$ & $2.00 \pm 0.20^{\mathrm{b}}$ & $2.86 \pm 0.27^{\mathrm{a}}$ \\
\hline & Moisture & $79.25 \pm 0.14^{\mathrm{a}}$ & $79.17 \pm 0.21^{\mathrm{a}}$ & $78.06 \pm 0.41^{\mathrm{b}}$ \\
\hline & Ash & $1.80 \pm 0.02^{\mathrm{c}}$ & $2.10 \pm 0.16^{\mathrm{b}}$ & $2.49 \pm 0.18^{\mathrm{a}}$ \\
\hline & $\begin{array}{l}\text { Average fish total } \\
\text { length }(\mathrm{cm})\end{array}$ & $7.71 \pm 0.76$ & $8.49 \pm 0.57$ & $6.98 \pm 0.45$ \\
\hline & $\begin{array}{l}\text { The average fish total } \\
\text { weight }(\mathrm{g})\end{array}$ & $4.24 \pm 1.31$ & $6.34 \pm 1.52$ & $3.11 \pm 0.56$ \\
\hline
\end{tabular}

\section{Fatty acid composition \\ General}

Fatty acid compositions of the sand smelt captured from Cekerek Dam in different seasons are given in Table 2. There were significant differences $(p<0.05)$ in the fatty acid (FA) profiles of the sand smelt among seasons. Total saturated fatty acids (SFA) and monounsaturated fatty acids (MUFA) level of sand smelt were the lowest in spring while sand smelt gave the highest level $(25.69 \%)$ in autumn for SFA, and autumn (26.43\%) and summer (26.30\%) for MUFA. Polyunsaturated fatty acids (PUFA) ranged from $28.29 \%$ in autumn to $36.11 \%$ in spring. Sand smelt contained a higher amount of PUFAs than MUFAs and SFA throughout different seasons $(\mathrm{p}<0.05)$. Seasonal differences in PUFA, MUFA, and SFA contents might be due to the differences in fish species, size and gender, ecological factors, feeding behavior, and food items availability.

\section{Saturated Fatty Acids (SFA)}

The main SFA were palmitic acid (C16:0, 15.76-16.19\%), stearic acid (C18:0, 4.54-5.17\%), followed by myristic acid (C14:0, 2.09-3.32\%) in three seasons. The dominant SFA in sand smelt were palmitic acid and stearic acid, contributing approximately $63.02-64.60 \%$ and $18.24-20.99 \%$ to the total SFA content respectively throughout different seasons (Table 2). It was found that the contents of stearic acid of sand smelt changed considerably during the seasons $(p<0.05)$ while no statistical differences were found for palmitic acid. Many authors have reported myristic, palmitic and stearic acid as major acids among SFAs for the same and other fish (Dal Bosco et al., 2019; Rahman et al., 1995; Tanakol et al., 1999; Yavuzer, 2020). Although, Dal Bosco et al. (2019) reported similar 
results value for stearic acid, Tanakol et al. (1999) and Yavuzer (2020) found higher results values of the amounts of palmitic acid and stearic acid in sand smelt from the Marmara Sea (27.1 -7.0\%) and Hirfanlı Dam, Turkey (26.85-6.40\%), respectively. The fatty acid profile of fish species is not constant and it changes according to many morphological and ecological factors such as species, season, life stage, location, diet, and age of the fish, which have effects on the nutrient composition of fish and even vary broadly within species and among species (Lunn and Theobald 2006; Ozogul et al. 2018).

The total SFA content of sand smelt was the highest in autumn, while the lower level of total SFA was observed in spring. There were significant differences $(p<0.05)$ among the seasons as regards total SFAs (Table 2). In general, SFA content was low $(<30 \%)$, except for certain species (Ackman 1989; Guler et al. 2008). Similar results were observed in our study during different seasons (21-28.14\%). Moreover, Öksüz et al. (2019), Luczynska et al. (2014) and Linhartová et al. (2018) were reported similar results for the same and other freshwater fish species.

\section{Monosaturated Fatty Acid (MUFA)}

The highest proportions of MUFA in the examined fish were oleic acid (C18:1n-9, 9.72-13.20\%), palmitoleic acid (C16:1n7, 5.49-8.26\%), and cis-vaccenic acid (C18:1n7, 3.43-4.29\%). Another minor MUFA detected was erucic acid $(\mathrm{C} 22: 1 \mathrm{n} 9,0.11-0.62)$. In terms of seasons, there were statistical differences in the fatty acid composition of fish species ( $p<0.05$ ), (Table 2 ).

Oleic acid was the main fatty acid among the MUFAs in the lipids of fish accounting for 46.84$50.19 \%$ of the total MUFAs, during different seasons in the present study. Dal Bosco et al. (2019) reported for sand smelt from Trasimeno Lake, slightly higher values of oleic (14.06\%) than those found in this study. Tanakol et al. (1999) observed for sand smelt caught in the Marmara Sea had a considerably lower value of this acid (4.6\%) compared to the results of this study for sand smelt $(9.72-$ 13.20\%). Bilgin et al. (2011) reported a little lower oleic acid (8.52\%) for sand smelt from Egirdir Lake in Turkey.

Palmitoleic acid was the second main MUFA in the lipids of five fish species studied, constituting about 26.45-31.40\% of the total MUFAs for all seasons. The highest palmitoleic acid was found in summer at $8.26 \%$. The results showed that sand smelt is a good source of palmitoleic acid. Prato and Biandolino (2012) and Yavuzer (2020) found similar variable palmitoleic contents in sand smelt. However, Tanakol et al. (1999) found very lower (2.9\%) and Dal Bosco et al. (2019) observed much higher values (10.72\%) of palmitoleic oleic acid for sand smelt than those found in this study (Table 2 ). The differences of oleic and palmitoleic acid contents in the same fish species could be due to the geographical location, size, muscle zone analyzed, sexual maturation, and catching season (Prato and Biandolino 2012).

The total MUFA content of sand smelt was the highest in autumn and summer while the lower level of total MUFA was observed in spring $(\mathrm{p}<0.05)$ (Table 2). The main reason for the high MUFA

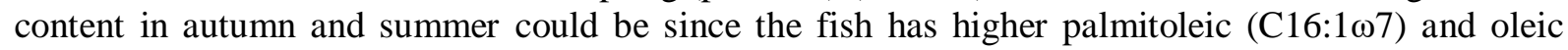
$(\mathrm{C} 18: 1 \omega 9)$ acid content in these seasons. Early studies have also shown that the level of unsaturation of total lipids in fish is conversely connected with the ecological temperatures (Vasconi et al. 2015). Moreover, sand smelt exhibited a lower content of MUFA (20.75-26.43\%) than the total PUFAs content $(28.29-36.11 \%)(\mathrm{p}<0.05)$ during all seasons, in the present study (Table 2). Also, Dal Bosco et al. (2019) and Prato and Biandolino, (2012) reported for sand smelt from Trasimeno Lake and from Mar Grande Sea had a much lower content of MUFA (31.56\% and $17.82 \%$ respectively) than contents of PUFAs.

\section{Polyunsaturated fatty acid (PUFA)}

The most represented PUFA in sand smelt were decosahexaenoic acid (DHA, C22:603, 12.33-

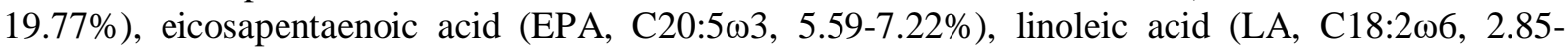

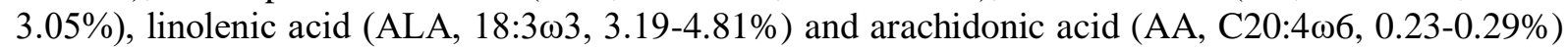
in all seasons. It was reported that the ratio of these FAs changed significantly during the seasons ( $\mathrm{p}<0.05)$, (Table 2). The percentages of dominant fatty acids found in our study were similar to the amounts reported in the literature for this species (Dal Bosco et al., 2019; Prato \& Biandolino, 2012; Tanakol et al., 1999).

The proportions of total PUFA of sand smelt were found to be $28.29 \%$ in autumn and $36.11 \%$ in spring and $31.28 \%$ in summer (Table 2). Similar results were found by Prato and Biandolino (2012), Dal Bosco et al. (2019), and Yavuzer (2020). Moreover, a seasonal variation in total levels of SFA, PUFA, and DHA was reported by Yanes-Roca et al. (2009), suggesting that PUFA is functionally 
important for fish's normal growth, development, and reproduction. The reproduction period of sand smelt in Cekerek Dam is in the period between April and June. In our study, the proportions of total PUFA was decreased slightly from March (36.11\%) to July (31.28\%) that represent before the beginning and the end of the reproduction period for sand smelt, respectively. PUFA can also be used for more reproductive purposes for this species, which is confirmed by studies by Yanes-Roca et al. (2009) and Köse et al. (2010) on the functionality of PUFA in fish.

It was very conspicuous that the higher PUFA values of sand smelt were mostly derived from the high DHA and EPA amounts in the present study. The PUFA consisted primarily of $\omega 3$ and $\omega 6$ PUFA

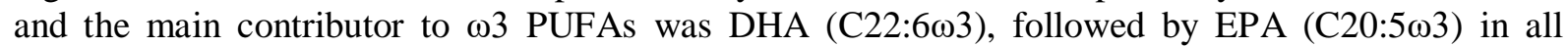
examined fish. The highest amounts of EPA and DHA were obtained from sand smelt $(7.22 \%$ $19.77 \%)$ in spring while sand smelt gave the lowest proportions of EPA and DHA (5.59\%-12.33\%) in autumn $(\mathrm{p}<0.05)$ (Table 2). Vasconi et al. (2015) observed a similar amount of EPA $(8.61 \%)$ and DHA (18.13\%) in sand smelt from Subalpine Lakes in Italy. Moreover, the highest total EPA and DHA values were found for sand smelt in spring (26.99\%) and followed by summer $(23.86 \%)$ $(\mathrm{p}<0.05)$ whereas the lowest total EPA and DHA $(17.92 \%)$ value was obtained from sand smelt in autumn. A close association between feeding activity and fatty acid composition of the muscle lipids was found by Vasconi et al. (2015). Sand smelt is a species of carnivorous or opportunistic predator; it feeds on zooplankton and benthic organisms (Bartulović et al. 2004; Benzer 2018). Moreover, many studies have shown that zooplankton abundance is the highest in spring and lowest in winter (Bulut, 2018; Bulut \& Saler, 2014). In general, zooplankton provides highly unsaturated fatty acids (HUFA) that are physiologically essential, such as eicosapentaenoic acid (EPA) and docosahexaenoic acid (DHA) (Keva et al., 2019; Makhutova et al., 2016). This could be clarified by the fact that these fish species consumed larger amounts of freshwater phytoplankton and zooplankton, which were abundant in 13 PUFA, in spring than in other seasons.

Generally low levels (e.g. 3.19- 4.81\%) of other $\omega 3$ fatty acids were found, one of which was linolenic acid $(18: 3 \omega 3)$, which showed significant differences $(\mathrm{p}<0.05)$ among the seasons. The highest linolenic acid was found in autumn at $4.81 \%$ while sand smelt gave the lowest amount of linolenic acid was found in summer at 3.19\% (Table 2). Dal Bosco et al. (2019) observed slightly higher values (5.45\%) of linolenic acid for sand smelt in autumn whereas Yavuzer (2020) observed very lower linolenic acid (0.43\%) content than those found in this study. Polat and Beklevik (1999) reported that many fish species the can convert linolenic acid to other long-chain $\omega-3$ series fatty acids such as EPA and DHA. The results showed that sand smelt is also a good source of PUFAs.

EPA and DHA, found only in fish and seafood, possess excessively beneficial effects to prevent coronary artery disease in humans (Guler et al. 2008; Leaf, A and Weber 1988). Although PUFAs (especially, EPA and DHA) are effectively synthesized only by aquatic organisms, human consumption of marine and freshwater products can provide these essential components (Özogul et al. 2007). These results indicated that the investigated all fish samples are a great source of EPA and DHA, especially in spring.

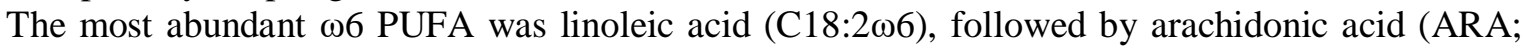

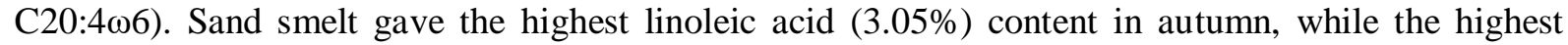
arachidonic acid (0.29\%) was in spring for sand smelt (Table 2). Yavuzer (2020) and Prato and Biandolino (2012) observed higher arachidonic acid and lower linoleic acid contents for the same species. Hoewever, Dal Bosco et al. (2019) found that higher arachidonic (5.14\%) and linoleic acid $(8.18 \%)$ content than our study results. These variations might be originated from the fatty acid composition of freshwater microalgae (Ahlgren et al., 1990, 1992), zooplankton feed (Caramujo et al. 2008; Desvilettes et al. 1997), and freshwater insects (Ghioni et al. 1996) that provide to the population of the lake ecosystems (Vasconi et al. 2015). Arachidonic acid like EPA and DHA is involved in maintaining cell membrane structure and function and also contributes to reproductive systems in fish (Cejas et al. 2004).

The amounts of $\omega 3$ PUFAs in sand smelt (ranging from $22.73 \%$ to $31.29 \%$ ) were higher than those of $\omega 6$ PUFAs (ranging from 3.98 to $4.95 \%$ ) in all seasons ( $\mathrm{p}<0.05$ ) (Table 2). These results are in an agreement with previous studies related to fatty acid profiles of freshwater fish species (Branciari et al., 2020; Dal Bosco et al., 2019; Yavuzer, 2020). Fish are the main nutritional source of essential unsaturated fatty acids, particularly EPA and DHA. However, they are not able to synthesize longchain $\omega 3$ PUFAs. Fish nourish on microorganisms (for instance algae) or on smaller fish that consume 
PUFA synthesizing micro-organisms, thence acquiring long-chain 03 PUFAs (Lunn \& Theobald, 2006; Prato \& Biandolino, 2012). Hence, the ratios of these 13 PUFAs in fish muscle are based on nourishment (Sargent et al., 2002) and their changes can be due to differences in the feeding habits of the fish (Norrbin et al. 1990; Prato and Biandolino 2012).

A maximum dietary ratio of $\omega 6 / \omega 3$ has been recommended as 4.0 (HMSO 1994). Levels higher than the maximum level are dangerous to human health and cause cardiovascular diseases (Dridi et al. 2017; Köse et al. 2010). In the present study, the $\omega 6 / \omega 3$ ratios in sand smelt were in the range of $0.15-$ 0.22 and the $\omega 6 / \omega 3$ ratio in this fish species during seasons did not surpass the suggested maximum level. Sand smelt showed the lowest $\omega 6 / \omega 3(0.15)$ ratio during spring and summer whereas the highest level of $\omega 6 / \omega 3$ (0.22) was in autumn (Table 2). The highest PUFA/SFA ratio (1.47) was obtained from sand smelt in spring although the lowest PUFA/SFA ratio was in autumn for sand smelt (Table 2). The PUFA/SFA proportion is 0.45 which is advised a minimum level of PUFA/SFA proportion (Piretti et al., 1988). Tanakol et al. (1999) reported higher than 1 for sand smelt, from the Black Sea, a PUFA/SFA. In the present study, this proportion did not surpass the suggested minimum ratio for sand smelt during seasons. 
Table 2. Seasonal variation on total (\%) fatty acid compositions in muscle lipids of the sand smelt from Cekerek (Süreyyabey) Dam.

\begin{tabular}{|c|c|c|c|}
\hline \multirow{2}{*}{$\begin{array}{l}\text { Fatty acids } \\
(\%)\end{array}$} & \multicolumn{3}{|c|}{ Sand smelt (Atherina boyeri) } \\
\hline & Autumn & Spring & Summer \\
\hline C12:0 & $0.08 \pm 0.00^{b}$ & $0.03 \pm 0.01^{\mathrm{c}}$ & $0.10 \pm 0.01^{\mathrm{a}}$ \\
\hline $\mathrm{C} 14: 0$ & $2.45 \pm 0.09^{b}$ & $2.09 \pm 0.19^{\mathrm{c}}$ & $3.32 \pm 0.11^{\mathrm{a}}$ \\
\hline $\mathrm{C} 15: 0$ & $0.57 \pm 0.02^{\mathrm{a}}$ & $0.45 \pm 0.02^{\mathrm{b}}$ & $0.48 \pm 0.03^{\mathrm{b}}$ \\
\hline C16:0 & $16.19 \pm 0.31^{\mathrm{a}}$ & $15.91 \pm 0.57^{\mathrm{a}}$ & $15.76 \pm 0.45^{\mathrm{a}}$ \\
\hline C17:0 & $0.84 \pm 0.03^{\mathrm{a}}$ & $0.52 \pm 0.01^{\mathrm{b}}$ & $0.43 \pm 0.02^{\mathrm{c}}$ \\
\hline C18:0 & $5.03 \pm 0.09^{\mathrm{a}}$ & $5.17 \pm 0.09^{\mathrm{a}}$ & $4.54 \pm 0.40^{\mathrm{b}}$ \\
\hline C20:0 & $0.18 \pm 0.01^{\mathrm{a}}$ & $0.13 \pm 0.02^{\mathrm{b}}$ & $0.05 \pm 0.01^{\mathrm{c}}$ \\
\hline $\mathrm{C} 22: 0$ & $0.11 \pm 0.03^{\mathrm{a}}$ & $0.08 \pm 0.03^{\mathrm{a}}$ & - \\
\hline $\mathrm{C} 24: 0$ & $0.23 \pm 0.13^{\mathrm{a}}$ & $0.24 \pm 0.02^{\mathrm{a}}$ & $0.21 \pm 0.03^{\mathrm{a}}$ \\
\hline ¿SFA & $25.69 \pm 0.39^{\mathrm{a}}$ & $24.63 \pm 0.25^{b}$ & $24.89 \pm 0.73^{a b}$ \\
\hline $\mathrm{C} 14: 1$ & $0.64 \pm 0.05^{\mathrm{a}}$ & $0.47 \pm 0.06^{\mathrm{b}}$ & $0.62 \pm 0.06^{\mathrm{a}}$ \\
\hline $\mathrm{C} 15: 1$ & $0.27 \pm 0.02^{\mathrm{a}}$ & $0.18 \pm 0.02^{\mathrm{b}}$ & $0.20 \pm 0.01^{\mathrm{b}}$ \\
\hline C16:1 & $7.32 \pm 0.37^{\mathrm{b}}$ & $5.49 \pm 0.54^{\mathrm{c}}$ & $8.26 \pm 0.23^{\mathrm{a}}$ \\
\hline $\mathrm{C} 17: 1$ & $0.19 \pm 0.01^{b}$ & $0.19 \pm 0.01^{\mathrm{b}}$ & $0.21 \pm 0.01^{\mathrm{a}}$ \\
\hline $\mathrm{C} 18: 1 \omega 9$ & $12.60 \pm 0.62^{\mathrm{a}}$ & $9.72 \pm 0.67^{\mathrm{b}}$ & $13.20 \pm 0.17^{\mathrm{a}}$ \\
\hline $\mathrm{C} 18: 1 \omega 7$ & $4.29 \pm 0.10^{\mathrm{a}}$ & $3.75 \pm 0.11^{\mathrm{b}}$ & $3.43 \pm 0.13^{c}$ \\
\hline C20:1 $1 \omega 9$ & $0.48 \pm 0.02^{\mathrm{a}}$ & $0.38 \pm 0.02^{\mathrm{b}}$ & $0.22 \pm 0.01^{\mathrm{c}}$ \\
\hline $\mathrm{C} 22: 1 \omega 9$ & $0.62 \pm 0.02^{\mathrm{a}}$ & $0.57 \pm 0.01^{\mathrm{b}}$ & $0.11 \pm 0.01^{\mathrm{c}}$ \\
\hline $\mathrm{C} 24: 1 \omega 9$ & $0.03 \pm 0.00^{\mathrm{b}}$ & - & $0.07 \pm 0.02^{\mathrm{a}}$ \\
\hline इMUFA & $26.43 \pm 0.98^{\mathrm{a}}$ & $20.75 \pm 1.30^{b}$ & $26.30 \pm 0.07^{\mathrm{a}}$ \\
\hline $\mathrm{C} 18: 2 \omega 6$ & $3.05 \pm 0.03^{\mathrm{a}}$ & $2.88 \pm 0.10^{\mathrm{b}}$ & $2.85 \pm 0.05^{\mathrm{b}}$ \\
\hline $\mathrm{C} 18: 3 \omega 6$ & $0.59 \pm 0.03^{\mathrm{a}}$ & $0.33 \pm 0.03^{\mathrm{b}}$ & $0.15 \pm 0.02^{c}$ \\
\hline $\mathrm{C} 18: 3 \omega 3$ & $4.81 \pm 0.40^{\mathrm{a}}$ & $4.31 \pm 0.28^{\mathrm{b}}$ & $3.19 \pm 0.20^{c}$ \\
\hline $\mathrm{C} 20: 2$ cis & $0.40 \pm 0.01^{\mathrm{a}}$ & $0.16 \pm 0.01^{\mathrm{c}}$ & $0.25 \pm 0.01^{\mathrm{b}}$ \\
\hline $\mathrm{C} 20: 3 \omega 6$ & $1.07 \pm 0.03^{\mathrm{a}}$ & $1.07 \pm 0.02^{\mathrm{a}}$ & $0.98 \pm 0.03^{b}$ \\
\hline $\mathrm{C} 20: 4 \omega 6$ & $0.23 \pm 0.01^{\mathrm{b}}$ & $0.29 \pm 0.01^{\mathrm{a}}$ & - \\
\hline $\mathrm{C} 20: 5 \omega 3$ & $5.59 \pm 0.11^{\mathrm{c}}$ & $7.22 \pm 0.21^{\mathrm{a}}$ & $6.01 \pm 0.30^{\mathrm{b}}$ \\
\hline $\mathrm{C} 22: 2$ cis & $0.21 \pm 0.02^{\mathrm{a}}$ & $0.10 \pm 0.01^{\mathrm{b}}$ & - \\
\hline $\mathrm{C} 22: 6 \omega 3$ & $12.33 \pm 0.51^{\mathrm{c}}$ & $19.77 \pm 1.36^{\mathrm{a}}$ & $17.85 \pm 0.57^{\mathrm{b}}$ \\
\hline ¿PUFA & $28.29 \pm 0.20^{c}$ & $36.11 \pm 1.18^{a}$ & $31.28 \pm 0.27^{b}$ \\
\hline PUFA/SFA & $1.10 \pm 0.01^{\mathrm{c}}$ & $1.47 \pm 0.03^{\mathrm{a}}$ & $1.26 \pm 0.05^{\mathrm{b}}$ \\
\hline$\Sigma \omega 3$ & $22.73 \pm 0.24^{c}$ & $31.29 \pm 1.32^{\mathrm{a}}$ & $27.05 \pm 0.24^{\mathrm{b}}$ \\
\hline$\Sigma \omega 6$ & $4.95 \pm 0.06^{\mathrm{a}}$ & $4.56 \pm 0.15^{\mathrm{b}}$ & $3.98 \pm 0.08^{\mathrm{c}}$ \\
\hline$\omega 6 / \omega 3$ & $0.22 \pm 0.00^{\mathrm{a}}$ & $0.15 \pm 0.01^{\mathrm{b}}$ & $0.15 \pm 0.00^{\mathrm{b}}$ \\
\hline DHA & $12.33 \pm 0.51^{\mathrm{c}}$ & $19.77 \pm 1.36^{\mathrm{a}}$ & $17.85 \pm 0.57^{\mathrm{b}}$ \\
\hline EPA & $5.59 \pm 0.11^{\mathrm{c}}$ & $7.22 \pm 0.21^{\mathrm{a}}$ & $6.01 \pm 0.30^{\mathrm{b}}$ \\
\hline DHA/EPA & $2.20 \pm 0.05^{\mathrm{b}}$ & $2.74 \pm 0.11^{\mathrm{a}}$ & $2.98 \pm 0.24^{\mathrm{a}}$ \\
\hline
\end{tabular}

Data are shown as mean \pm standard deviation (SD). SFA: saturated fatty acid; MUFA: monounsaturated fatty acid; PUFA: polyunsaturated fatty acid; DHA: docosahexaenoic acid; EPA:eicoesapentaenoic acid; $\Sigma$ n-6 PUFA: total n-6 polyunsaturated fatty acid; $\Sigma$ n-3 PUFA: total n-3 polyunsaturated fatty acid. Different letters (a-c) in the same row for each fish indicate significant differences in Table 2 ( $<<0.05$ ).

\section{CONCLUSION}

This study represented seasonal variability in proximate and FA composition of muscle tissue from economically important sand smelt caught in Cekerek Sureyyabey Dam. To the authors' knowledge, it is the first time that an evaluation of the proximate and fatty acid composition of sand smelt from Cekerek Sureyyabey Dam has been carried out. According to our results, the proximate and FA composition values of sand smelt showed differences during seasons. These variations in fatty acids are due to environmental, other ecological, and morphological influences and also depend on their natural nutrition and feeding habits. Sand smelt gave higher lipid contents in summer. Moreover, the total EPA and DHA (\%) value of the fish species was the highest in spring. In addition, sand smelt, the carnivorous fish, gave the higher PUFA value than the content of SFA and MUFA during all seasons and also had the highest total EPA+DHA value $(26.99 \%)$ and total $\omega 3$ value in spring $(\mathrm{p}<0.05)$. This study exhibit that these fish species are a good source of nutrients and these species seem to be appropriate for the human diet, although there were differences in lipid and fatty acid composition during seasons. 


\section{ACKNOWLEDGEMENT}

The author would like to thank the Department of Project Coordination Application and Research

Center of Yozgat Bozok University for their support (Project Number: 6602a-Turizm/18-225). The author wishes to thank Professor Yesim Özogul for her valuable contributions and supports and Dr. Mustafa Durmus for his help during the research.

\section{REFERENCES}

Abedi, E., \& Sahari, M. A. (2014). Long-chain polyunsaturated fatty acid sources and evaluation of their nutritional and functional properties. In Food Science and Nutrition (Vol. 2, Issue 5, pp. 443-463). https://doi.org/10.1002/fsn3.121

Abou-Zied, A. S., Talab, A. S., Ibrahim, M. A., \& Ibrahim, S. M. (2020). Quality attributes of artificial dried and dried salted sand smelt fish (Atherina boyeri). Egyptian Journal of Aquatic Biology and Fisheries, 24(7 Special issue), 307-317. https://doi.org/10.21608/EJABF.2020.120338

Ackman, R. G. (1989). Nutritional composition of fats in seafoods. In Progress in Food and Nutrition Science (Vol. 13, Issues 3-4, pp. 161-289).

Ahlgren, G., Gustafsson, I. -B, \& Boberg, M. (1992). Fatty Acid Content and Chemical Composition of Freshwater Microalgae. Journal of Phycology, 28(1), 37-50. https://doi.org/10.1111/j.00223646.1992.00037.x

Ahlgren, G., Lundstedt, L., Brett, M., \& Forsberg, C. (1990). Lipid composition and food quality of some freshwater phytoplankton for cladoceran zooplankters. Journal of Plankton Research, 12(4), 809-818. https://doi.org/10.1093/plankt/12.4.809

Alasalvar, C., Taylor, K. D. A., Zubcov, E., Shahidi, F., \& Alexis, M. (2002). Differentiation of cultured and wild sea bass (Dicentrarchus labrax): Total lipid content, fatty acid and trace mineral composition. Food Chemistry, 79(2), 145-150. https://doi.org/10.1016/S0308-8146(02)00122-X

Ali, M., Imran, M., Nadeem, M., Khan, M. K., Sohaib, M., Suleria, H. A. R., \& Bashir, R. (2019). Oxidative stability and Sensoric acceptability of functional fish meat product supplemented with plant - based polyphenolic optimal extracts. Lipids in Health and Disease, 18(1). https://doi.org/10.1186/s12944-0190982-y

AOAC. (1984). Official Methods of Analysis of AOAC International 14th. Ed. In Association of Official Analysis Chemists International. Washington, DC, USA.

AOAC. (1998). Official methods of analysis of the Association of Official Analytical Chemists International. In Official methods of analysis 16th. Ed. Association of Official Analytical Chemists. International, Inc., Gaithersburg, Maryland, USA., CD-ROM.

Bandarra, N. M., Batista, I., Nunes, M. L., \& Empis, J. M. (2001). Seasonal variation in the chemical composition of horse-mackerel (Trachurus trachurus). European Food Research and Technology, 212(5), 535-539. https://doi.org/10.1007/s002170100299

Bartulović, V., Glamuzina, B., Conides, A., Dulčić, J., Lučić, D., Njire, J., \& Kožul, V. (2004). Age, growth, mortality and sex ratio of sand smelt, Atherina boyeri Risso, 1810 (Pisces: Atherinidae) in the estuary of the Mala Neretva River (middle eastern Adriatic, Croatia). Journal of Applied Ichthyology, 20(5), 427430. https://doi.org/10.1111/j.1439-0426.2004.00560.x

Benzer, S. (2018). First Record of the Sand Smelt Atherina boyeri Risso, 1810 in the Süreyyabey Dam Lake, Yeşilırmak Basin, Turkey. Annals of Biological Sciences, 6(2), 38-42.

Bilgin, S.., Çetinkaya, S., \& Bolat, Y. (2011). Changes on the nutritional compositions of the sand smelt (Atherina Boyeri Risso, 1810) marinade during storage. African Journal of Biotechnology, 10(16), 31973203. https://doi.org/10.5897/ajb10.2067

Bligh, E. G., \& Dyer, W. J. (1959). A rapid method of total lipid extraction and purification. Canadian Journal of Biochemistry and Physiology, 37(8), 911-917. https://doi.org/10.1139/o59-099

Bouriga, N., Mili, S., Ennouri, R., Quignard, J. P., Trabelsi, M., \& Faure, E. (2014). Reproductive parameters and seasonal variation in fatty acid composition of Atherina boyeri s. str. and A. lagunae populations from open sea, lagoonand island coasts of Tunisia. Cahiers de Biologie Marine, 55(2), 201-212. https://doi.org/10.21411/cbm.a.cc1ba07d

Branciari, R., Franceschini, R., Roila, R., Valiani, A., Pecorelli, I., Piersanti, A., Haouet, N., Framboas, M., \& Ranucci, D. (2020). Nutritional value and contaminant risk assessment of some commercially important fishes and crawfish of lake Trasimeno, Italy. International Journal of Environmental Research and Public Health, 17(7). https://doi.org/10.3390/ijerph17072545

Bulut, H. (2018). Kapıaçmaz Göleti (Kovancılar, Elazığ) Zooplankton'unun Mevsimsel Değişimi. Turkish Journal of Agriculture - Food Science and Technology, 6(11), 1617. https://doi.org/10.24925/turjaf.v6i11.1617-1621.2106 
Bulut, H., \& Saler, S. (2014). Murat Nehri’nin (Elazığ-Palu İlçe Merkezi Sınırları İçindeki Bölümün’de) Zooplanktonu ve Değişimi. Turkish Journal of Agriculture - Food Science and Technology, 2(1), 13. https://doi.org/10.24925/turjaf.v2i1.13-17.32

Caramujo, M. J., Boschker, H. T. S., \& Admiraal, W. (2008). Fatty acid profiles of algae mark the development and composition of harpacticoid copepods. Freshwater Biology, 53(1), 77-90. https://doi.org/10.1111/j.1365-2427.2007.01868.X

Cejas, J. R., Almansa, E., Jérez, S., Bolaños, A., Samper, M., \& Lorenzo, A. (2004). Lipid and fatty acid composition of muscle and liver from wild and captive mature female broodstocks of white seabream, Diplodus sargus. Comparative Biochemistry and Physiology - B Biochemistry and Molecular Biology, 138(1), 91-102. https://doi.org/10.1016/j.cbpc.2004.03.003

Chrisafi, E., Kaspiris, P., \& Katselis, G. (2007). Feeding habits of sand smelt (Atherina boyeri, Risso 1810) in Trichonis Lake (Western Greece). Journal of Applied Ichthyology, 23(3), 209-214. https://doi.org/10.1111/j.1439-0426.2006.00824.x

Connor, W. E. (2000). Importance of n-3 fatty acids in health and disease. American Journal of Clinical Nutrition, 71(1 SUPPL.), 171-175. https://doi.org/10.1093/ajcn/71.1.171s

Çevik, C., Gündoğdu, S., \& Alagöz Ergüden, S. (2018). New Record of the Big-Scale Sand Smelt Atherina boyeri Risso, 1810 (Atherinidae) in the Seyhan Dam Reservoir (Seyhan River Basin, Turkey). Natural and Engineering Sciences, 133-140. https://doi.org/10.28978/nesciences.424658

Dal Bosco, A., Mattioli, S., Mancini, S., Cartoni Mancinelli, A., Cotozzolo, E., \& Castellini, C. (2019). Nutritional composition of raw and fried big-scale sand smelt (Atherina boyeri) from trasimeno lake. Italian Journal of Animal Science, 18(1), 608-614. https://doi.org/10.1080/1828051X.2018.1548915

Desvilettes, C., Bourdier, G., Amblard, C., \& Barth, B. (1997). Use of fatty acids for the assessment of zooplankton grazing on bacteria, protozoans and microalgae. Freshwater Biology, 38(3), 629-637. https://doi.org/10.1046/j.1365-2427.1997.00241.x

Dridi, S., Romdhane, M. S., \& Cafsi, M. El. (2017). Nutritional quality in terms of lipid content and fatty acid composition of neutral and polar lipids in the adductor muscle of the oyster Crassostrea gigas (Thunberg, 1794) farmed in the Bizert lagoon (Tunisia) in relation with sexual cycle and environmen. Egyptian Journal of Aquatic Research, 43(4), 329-336. https://doi.org/10.1016/j.ejar.2017.10.001

Effiong, B.N. and Mohammed, I. (2008). Effect of seasonal variation on the Nutrient composition in selected fish species in Lake Kainji - Nigeria. Nature and Science, 6(2), 2-6.

Ekmekçi, F. G., Kırankaya, Ş. G., Gençoğlu, L., \& Yoğurtçuoğlu, B. (2013). Present status of invasive fishes in inland waters of Turkey and assessment of the effects of invasion. Istanbul University Journal of Fisheries \& Aquatic Sciences, 28(July), 105-140.

Fallah, A. A., Nematollahi, A., \& Saei-Dehkordi, S. S. (2013). Proximate composition and fatty acid profile of edible tissues of Capoeta damascina (Valenciennes, 1842) reared in freshwater and brackish water. Journal of Food Composition and Analysis, 32(2), 150-154. https://doi.org/10.1016/j.jfca.2013.09.004

Ghioni, C., Bell, J. G., \& Sargent, J. R. (1996). Polyunsaturated fatty acids in neutral lipids and phospholipids of some freshwater insects. Comparative Biochemistry and Physiology - B Biochemistry and Molecular Biology, 114(2), 161-170. https://doi.org/10.1016/0305-0491(96)00019-3

Gogus, U., \& Smith, C. (2010). N-3 omega fatty acids: a review of current knowledge. In International Journal of Food Science and Technology. https://doi.org/10.1111/j.1365-2621.2009.02151.x

Görgün, S., Akpinar, N., \& Dirican, S. (2014). A comparative study on the fatty acid profiles of total lipid, neutral and polar lipids in the liver and muscle of capoeta sieboldii (steindachner, 1864) and capoeta baliki (Turan, kottelat, ekmekçi, Imamoğlu, 2006) from Tödürge lake (Sivas, Turkey). Acta Alimentaria, 43(1), 170-181. https://doi.org/10.1556/AAlim.43.2014.1.17

Guler, G. O., Kiztanir, B., Aktumsek, A., Citil, O. B., \& Ozparlak, H. (2008). Determination of the seasonal changes on total fatty acid composition and $\omega 3 / \omega 6$ ratios of carp (Cyprinus carpio L.) muscle lipids in Beysehir Lake (Turkey). Food Chemistry, 689-694. https://doi.org/10.1016/j.foodchem.2007.10.080

Ichihara, K. N. ich., Shibahara, A., Yamamoto, K., \& Nakayama, T. (1996). An improved method for rapid analysis of the fatty acids of glycerolipids. Lipids, 31(5), 535-539. https://doi.org/10.1007/BF02522648

Inhamuns, A. J., \& Franco, M. R. B. (2008). EPA and DHA quantification in two species of freshwater fish from Central Amazonia. Food Chemistry, 107(2), 587-591. https://doi.org/10.1016/j.foodchem.2007.07.032

Izci, L., Bilgin, Ş., \& Günlü, A. (2011a). Production of fish finger from sand smelt (Atherina boyeri, RISSO 1810) and determination of quality changes. African Journal of Biotechnology, 10(21), 4464-4469. https://doi.org/10.5897/AJB10.2093

Izci, L., Günlü, A., \& Bilgin, Ş. (2011b). Production of fish chips from sand smelt (Atherina boyeri, RISSO 1810) and determination of some quality changes. Iranian Journal of Fisheries Sciences, 10(2), 230-241. 
James Henderson, R., \& Tocher, D. R. (1987). The lipid composition and biochemistry of freshwater fish. In Progress in Lipid Research (Vol. 26, Issue 4, pp. 281-347). https://doi.org/10.1016/0163-7827(87)900026

Keva, O., Tang, P., Käkelä, R., Hayden, B., Taipale, S. J., Harrod, C., \& Kahilainen, K. K. (2019). Seasonal changes in European whitefish muscle and invertebrate prey fatty acid composition in a subarctic lake. Freshwater Biology, 64(11), 1908-1920. https://doi.org/10.1111/fwb.13381

Kinsella, J. (1987). Seafoods and fish oils in human health and disease. New York: Marcel Dekker.

Köse, S., Koral, S., Özoĝul, Y., \& Tufan, B. (2010). Fatty acid profile and proximate composition of Pacific mullet (Mugil so-iuy) caught in the Black Sea. International Journal of Food Science and Technology, 45(8), 1594-1602. https://doi.org/10.1111/j.1365-2621.2010.02309.x

Kris-Etherton, P. M., Harris, W. S., \& Appel, L. J. (2002). Fish consumption, fish oil, omega-3 fatty acids, and cardiovascular disease. In Circulation (Vol. 106, Issue 21, pp. 2747-2757). https://doi.org/10.1161/01.CIR.0000038493.65177.94

Lauriano, E. R., Faggio, C., Capillo, G., Spanò, N., Kuciel, M., Aragona, M., \& Pergolizzi, S. (2018). Immunohistochemical characterization of epidermal dendritic-like cells in giant mudskipper, Periophthalmodon schlosseri. Fish and Shellfish Immunology, 74, 380-385. https://doi.org/10.1016/j.fsi.2018.01.014

Leaf, A., \& Weber, P. C. (1988). No Title. New England Journal of Medicine, 318, 549-555.

Leaf, Alexander, Kang, J. X., Xiao, Y. F., \& Billman, G. E. (2003). Clinical prevention of sudden cardiac death by n-3 polyunsaturated fatty acids and mechanism of prevention of arrhythmias by n-3 fish oils. In Circulation (Vol. 107, Issue 21, pp. 2646-2652). https://doi.org/10.1161/01.cir.0000069566.78305.33

Linhartová, Z., Krejsa, J., Zajíc, T., Másílko, J., Sampels, S., \& Mráz, J. (2018). Proximate and fatty acid composition of 13 important freshwater fish species in central Europe. Aquaculture International, 26(2), 695-711. https://doi.org/10.1007/s10499-018-0243-5

Luczynska, J., Paszczyk, B., \& Luczynski, M. J. (2014). Fatty acid profiles in marine and freshwater fish from fish markets in northeastern Poland. Archives of Polish Fisheries, 22(3), 181-188. https://doi.org/10.2478/aopf-2014-0018

Lunn, J., \& Theobald, H. E. (2006). The health effects of dietary unsaturated fatty acids. Nutrition Bulletin, 31(3), 178-224. https://doi.org/10.1111/j.1467-3010.2006.00571.x

Mahadevan, G., Pouladi, M., Stara, A., \& Faggio, C. (2019). Nutritional evaluation of elongate mudskipper Pseudapocryptes elongatus (Cuvier, 1816) from Diamond Harbor, West Bengal, India. Natural Product Research. https://doi.org/10.1080/14786419.2019.1666388

Makhutova, O. N., Shulepina, S. P., Sharapova, T. A., Dubovskaya, O. P., Sushchik, N. N., Baturina, M. A., Pryanichnikova, E. G., Kalachova, G. S., \& Gladyshev, M. I. (2016). Content of polyunsaturated fatty acids essential for fish nutrition in zoobenthos species. Freshwater Science, 35(4), 1222-1234. https://doi.org/10.1086/688760

Massresha, E., Mateos, H., Lewandowski, P., \& Zewdue, A. (2017). Proximate Composition and Fatty Acid Content of Commercially Important Fish Species from Ethiopian Lakes: A Review. World Journal of Food Science and Technology, 1(3), 105-114. https://doi.org/10.11648/j.wjfst.20170103.14

Norrbin, M. F., Olsen, R. E., \& Tande, K. S. (1990). Seasonal variation in lipid class and fatty acid composition of two small copepods in Balsfjorden, northern Norway. Marine Biology, 105(2), $205-211$. https://doi.org/10.1007/BF01344288

Öksüz, A., Dikmen, M., Alkan, Ş. B., Yaylalı, O., \& Demirtaş, S. (2019). Beyşehir Gölünden Avlanan Sazan ve Sudak Balıklarının Besin ve Yağ Asidi Bileşenlerinin Karşılaştırılması. Aquatic Research, 9(1), 13-17.

Özogul, Y., Özogul, F., \& Alagoz, S. (2007). Fatty acid profiles and fat contents of commercially important seawater and freshwater fish species of Turkey: A comparative study. Food Chemistry, 103(1), $217-223$. https://doi.org/10.1016/j.foodchem.2006.08.009

Özogul, Y., Özogul, F., Çiçek, E., Polat, A., \& Kuley, E. (2009). Fat content and fatty acid compositions of 34 marine water fish species from the Mediterranean Sea. International Journal of Food Sciences and Nutrition, 60(6), 464-475. https://doi.org/10.1080/09637480701838175

Ozogul, Y., Polat, A., Uçak, I., \& Ozogul, F. (2011). Seasonal fat and fatty acids variations of seven marine fish species from the Mediterranean Sea. European Journal of Lipid Science and Technology, 113(12), 14911498. https://doi.org/10.1002/ejlt.201000554

Ozogul, Y., Ucar, Y., Takadaş, F., Durmus, M., Köşker, A. R., \& Polat, A. (2018). Comparision of Green and Conventional Extraction Methods on Lipid Yield and Fatty Acid Profiles of Fish Species. European Journal of Lipid Science and Technology, 120(12). https://doi.org/10.1002/ejlt.201800107

Piretti, M. V., Zuppa, F., Pagliuca, G., \& Taioli, F. (1988). Investigation of the seasonal variations of fatty acid constituents in selected tissues of the bivalve mollusc scapharca inaequivalvis (bruguiere). Comparative Biochemistry and Physiology -- Part B: Biochemistry And 89(1), 183-187. https://doi.org/10.1016/03050491(88)90281-7 
Polat, A., \& Beklevik, G. (1999). The Importance of $\omega-3$ Series Fatty Acids in Marine Fish Larvae Nutrition and Recent Developments. Turkish Journal of Veterinary and Animal Sciences, 23(EK3), 525-530.

Prato, E., \& Biandolino, F. (2012). Total lipid content and fatty acid composition of commercially important fish species from the Mediterranean, Mar Grande Sea. Food Chemistry, 131(4), 1233-1239. https://doi.org/10.1016/j.foodchem.2011.09.110

Quignard, J.-P., \& Pras, A. (1986). Wrasses: Family Labridae. In Fishes of the north-eastern Atlantic and the Mediterranean.

Rahman, S. A., Huah, T. S., Nassan, O., \& Daud, N. M. (1995). Fatty acid composition of some Malaysian freshwater fish. Food Chemistry, 54(1), 45-49. https://doi.org/10.1016/0308-8146(95)92660-C

Rasoarahona, J. R. E., Barnathan, G., Bianchini, J. P., \& Gaydou, E. M. (2005). Influence of season on the lipid content and fatty acid profiles of three tilapia species (Oreochromis niloticus, O. macrochir and Tilapia rendalli) from Madagascar. Food Chemistry, 91(4), https://doi.org/10.1016/j.foodchem.2004.07.001

Robert, A., Mfilinge, P., Limbu, S. M., \& Mwita, C. J. (2014). Fatty Acid Composition and Levels of Selected Polyunsaturated Fatty Acids in Four Commercial Important Freshwater Fish Species from Lake Victoria, Tanzania. Journal of Lipids, 2014, 1-7. https://doi.org/10.1155/2014/712134

Sargent, J.., Tocher, D. R., \& Bell, J. . G. (2002). The lipids. In J.. E. W. Halver \& R. Hardy (Eds.), Fish Nutrition (pp. 181-257). Elsevier (Academic Press).

Schmidt, E. B., Arnesen, H., De Caterina, R., Rasmussen, L. H., \& Kristensen, S. D. (2005). Marine n-3 polyunsaturated fatty acids and coronary heart disease: Part I. Background, epidemiology, animal data, effects on risk factors and safety. In Thrombosis Research (Vol. 115, Issue 3, pp. 163-170). https://doi.org/10.1016/j.thromres.2004.09.006

Sidhu, K. S. (2003). Health benefits and potential risks related to consumption of fish or fish oil. Regulatory Toxicology and Pharmacology, 38(3), 336-344. https://doi.org/10.1016/j.yrtph.2003.07.002

Simopoulos, A. P. (1991). Omega-3 fatty acids in health and disease and in growth and development. In American Journal of Clinical Nutrition (Vol. 54, Issue 3, pp. 438-463). https://doi.org/10.1093/ajcn/54.3.438

Smida, M. A. Ben, Bolje, A., Ouerhani, A., Barhoumi, M., Mejri, H., Cafsi, M. El, \& Fehri-Bedoui, R. (2014). Effects of Drying on the Biochemical Composition of \&lt; i\&gt;Atherina boyeri\&lt;/i\&gt; from the Tunisian Coast. Food and Nutrition Sciences, 05(14), 1399-1407. https://doi.org/10.4236/fns.2014.514152

Tanakol, R., Yazici, Z., Şener, E., \& Sencer, E. (1999). Fatty acid composition of 19 species of fish from the Black Sea and the Marmara sea. Lipids, 34(3), 291-297. https://doi.org/10.1007/s11745-999-0366-8

Teame, T., Natarajan, P., \& Tesfay, Z. (2015). Proximate and mineral composition of some commercially important fish species of tekeze reservoir and lake Hashenge, Ethiopia. Journal of Fisheries and Aquatic Studies, 4(1), 160-164.

Vasconi, M., Caprino, F., Bellagamba, F., Busetto, M. L., Bernardi, C., Puzzi, C., \& Moretti, V. M. (2015). Fatty acid composition of freshwater wild fish in subalpine lakes: A comparative study. Lipids, 50(3), $283-302$. https://doi.org/10.1007/s11745-014-3978-4

Yavuzer, E. (2020). Comparing the fatty acid level of sand smelt (Atherina boyeri) with rainbow trout (Oncorhynchus mykiss) as a cheaper protein and fatty acid source. Acta Aquatica Turcica, 107-112. https://doi.org/10.22392/actaquatr.603538 